International Journal of Sustainable Energy and Environmental

Research

2021 Vol. 10, No. 2, pp. 85-100.

$\operatorname{ISSN}(e): 2306-6253$

$\operatorname{ISSN}(p): 2312-5764$

DOI: 10.18488/journal.13.2021.102.85.100

(C) 2021 Conscientia Beam. All Rights Reserved.

check for
updates

\title{
PRESENTING AN ENERGY-EFFICIENT MODEL FOR THE ENVELOPE OF HIGH-RISE OFFICE BUILDINGS CASE STUDY: COLD AND DRY CLIMATE
}

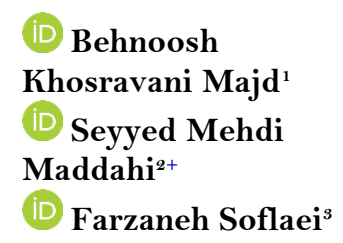

Received: 28 July 2021

Revised: 30 August 2021

Accepted: 21 September 2021

Published: 13 October 2021

Keywords

Building integrated photovoltaics (BIPV)

Design optimization

Envelope

Energy efficiency

High-rise building

Sustainability.

\author{
${ }^{1}$ Master Graduated from Department of Architecture in Khavaran Institute \\ of Higher Education, Mashhad, Iran. \\ Email:khosravanimajdbrhnoosh@gmail.com Tel:+989153382326 \\ 'Assistant Professor, Department of Architecture in Khavaran Institute of \\ Higher Education, Mashhad, Iran. \\ Email:sm.madahi@gmail.com Tel: +989153177726 \\ ${ }^{s}$ Assistant Professor, Department of Architecture, State University of New \\ Tork at Delhi, USA. \\ Email: Soflaeff@delhi.edu Tel: +1(443)787-6781
}

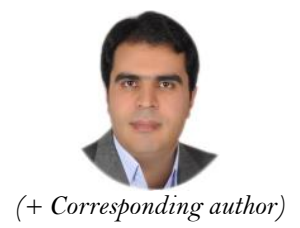

(+ Corresponding author)

\section{ABSTRACT}

The expansion of high-rise buildings and vertical cities has made room for a significant potential for large areas in the envelope (façade) of buildings to produce the required energy. This opens the opportunity to conduct research about the city of MashhadIran. This study aims to provide an optimal model of the envelope of an office building and maximum utilization of sunlight in providing energy and indoor lighting in cold and dry climates. DesignBuilder software, version 6.1.0.006, to simulate the building and Energy plus 8.9 simulator engine was used to compare the amount of energy consumed, and electricity generated. We evaluated the data by the analytical-comparative method. The results showed that ,in one year, the energy produced by model number one (\#1) (27.6\%) and model number two (\#2) $(18.7 \%)$, among other simulated models with $15 \%$ efficiency (base efficiency rate) regarding all solar factors used in them, the amount of the electricity generated manifests a significant difference from the total electricity consumption of the building studied, assuming that the percentage of electricity supply with the actual efficiency of the proposed solar factors, are $17.99 \%$ and $17.88 \%$, in model (\#1) and model (\#2). Once compared the given results of the models used for the photovoltaic panels, photovoltaic solar glasses, and the occupied area by them, a direct impact on the efficiency and energy generation of the building model envelope was seen. So, this study paves the road for further use of new technologies of building-integrated photovoltaic (BIPV) for locations that have similar climate.

Contribution/Originality: This study documents that a rarely designed optimal model can be applied for the envelope of office high-rise buildings through integrated photovoltaic (BIPV) systems to optimize indoor daylighting and energy efficiency in Iran's cold and dry climate in order to enhance occupants' health, well-being and productivity towards a sustainable future.

\section{INTRODUCTION}

It is the abundance, cleanliness and availability of solar energy that makes it a long-lasting source of energy, also known as the most promising alternative, specifically for the Global Renewable (Sustainability) Plan (Siddiqui et al., 2017; Wang et al., 2018). Electricity can be considered as the heart of modern economies that offers an 
increasing share of energy services. Due to increasing currents of electricity, transportation, heating, and a dramatic demand growth for digital communication gadgets, as well as air conditioning, electricity has become the utmost priority in humans' list of needs. Renewable energy here plays a principal role in providing electricity for everyone.

Buildings can be ranked among the leading consumers of energy and CO2 emitters (Chen et al., 2012). Highrise buildings are large consumers of energy. They account for the dominant elements in urban architecture on account of their scale and purpose and therefore, environmentally friendly designs must be spotlighted. Many architects, engineers, and designers believe that properly designed and constructed buildings in large and dense cities can be a representation of sustainability progress and green architecture. Evidently, this belief has led them to minimize adverse factors affecting the environment to maintain the health and wellbeing of residents (Nouhi, 2000). Given the fact that the major part of sustainable development happens in the building sector, countless economic activities could be done to reduce greenhouse gas emissions in this sector (Borbon-Almada, Rodriguez-Muñoz, \& Najera-Trejo, 2019). In case a solution is proposed, as long as it is economically viable and well-integrated into the existing architecture, we can expect a reasonable process of energy consumption. With the rapid decline in natural resources, the utilization of renewable energy solar for instance, is being the number-one alternative on the boil (Norton et al., 2011).

Based on IRENA analysis, solar PV power installations could grow almost six-fold over the next ten years, reaching a cumulative capacity of $2840 \mathrm{GW}$ globally by 2030 and rising to $8519 \mathrm{GW}$ by 2050 . This implies that the total installed capacity of PV in 2050 will almost be eighteen times higher than it was in 2018 (IRENA, 2019). The use of photovoltaic (PV) panels or glass for PV facades has shown that it has a profound effect on the overall energy consumption of buildings, particularly through its efficacy on PV electricity generation, lighting, cooling, and heating (Jiang, Zhou, Lu, Han, \& Wang, 2008; Miyazaki, Akisawa, \& Kashiwagi, 2005).

Seemingly, a myriad of technologies now offers ways and alternatives for the very sake of reducing energy consumption in buildings and different forms of environmental pollution. A viable item among various developing technologies, building-integrated photovoltaics (BIPV) can play a role in reducing destructive environmental effects by converting sunlight into electricity (Chae, Jeehwan, Park, \& Byungha, 2014). This system is one of the most effective methods for generating energy from the Sun (Radwan \& Osama, 2016). Photovoltaic panels integrated with buildings not only generate electricity but are also part of the building (Eiffert, 2000).

In BIPV systems, PV cells replace conventional building materials and convert them into active elements (Henemann, 2008). BIPV systems replace some common building materials and components in building envelopes, such as roofs and facades. According to Peng, Huang, and Wu (2011) BIPV systems are either considered to be a functional part of building structure or architecturally integrated into building design (Peng et al., 2011). Hence, the BIPV system acts as a type of building material and envelope while simultaneously generating power (Strong, 2016). Building-integrated Photovoltaics (BIPV) is the integration of photovoltaic cells into different parts of a building. PV modules have double functions; they are both an alternative to the materials used in the building facade and an energy generator for the premises. Photovoltaic panels are integrated into the building to provide the following: solar protection, weather protection, sunlight modulation, thermal insulation, sound insulation, and security (Debbarma, Sudhakar, \& Baredar, 2017). Figure 1 shows a global market point of view of integrated photovoltaic technology.

Predominantly, most building surfaces can fit for being integrated with photovoltaic modules. And they can be classified into four main categories: 1) index photovoltaics (including curtain wall products, spandrel panels, etc.), 2) ceiling photovoltaics (including tiles, skylights, etc.), 3) window photovoltaics (including glass laminates) -Glass, transparent thin films, etc.) And 4) photovoltaic awnings (including panels, louvers, curtains, etc.) (Maturi \& Adami, 2018; Pester \& Crick, 2013; Sonnenenergie, 2008; Stamatakis, Mandalaki, \& Tsoutsos, 2016). 


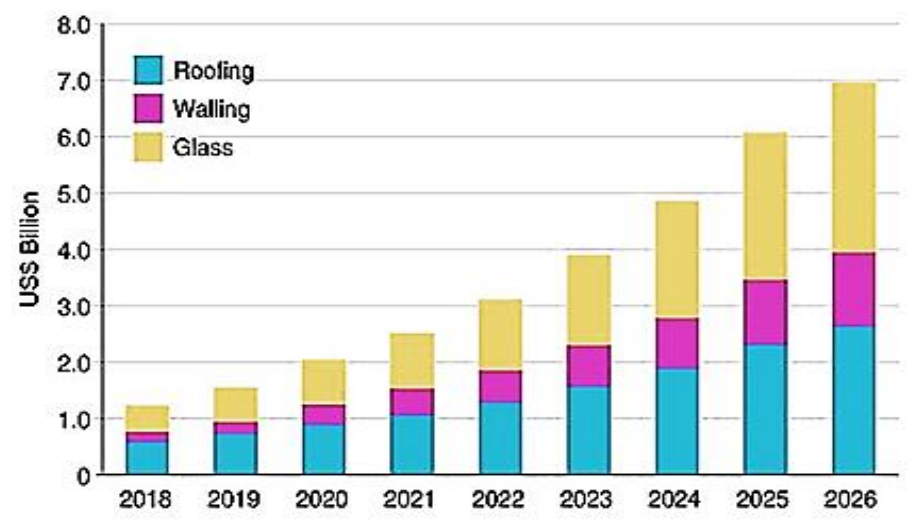

Figure-1. Global Market Outlook (2018-2026) About integrated thinking for photovoltaics in buildings. Source: Ballif, Perret-Aebi, Lufkin, and Rey (2018).

Since the boundary is between the interior and exterior spaces of the building envelope, which plays an important role in the building's energy consumption, the building's covering studies report that half of the building's energy consumption is related to its cooling and heating (World Energy Resources, 2013). As for the sustainable design, the building envelope is evolving towards ecological and environmental compatibility and dynamic adjustability (Norton et al., 2011; Zawidzki, 2015).

Facade is the main component of a building and so defines its appearance. It acts as a barrier between the interior and the exterior space. The facade is a shield against sun exposure and reduces heating/cooling loads, therefore, enhances daylight distribution (EU, 2010; Nagy et al., 2016). The building's facade separates the interior from the exterior part. Yet, that must also transmit reasonable light to the inside and create an efficacious connection between the two spaces (Debbarma., Sudhakar, \& Baredar, 2017).

Appling BIPV to urban areas facilitates the absorption and conversion of solar energy via buildings' envelope for integrating with the photovoltaic module. The use of BIPV in the facade of modern buildings has become common in countries with higher latitudes (Jiang et al., 2008; Lam, Li, \& Cheung, 2003). Although solar radiation in vertical surfaces is much lower than horizontal ones (Khoo et al., 2013) applying roof installations are limited (Xu, Reed, \& Reindl, 2016) and facade installations should be used as a means of generating electricity from renewable energy sources (Hachem, Athienitis, \& Fazio, 2014). Hence, the BIPV system acts as a type of building material and shell which generates power at the same time (Strong, 2016).

Accordingly, high-rise buildings -the main consumers of energy in urban areas- should serve as a site for solar PV. The facade of high-rise buildings offers an excellent opportunity to use solar PV (Aseem, Sharma, \& Kothari, 2017). Solar PV facade is aesthetically pleasing, generates electricity, and contributes to better building energy performance. Transparency in solar PV facades has been seen by distances between solar cells or through thin-film solar cells. Light works can also create beautiful patterns in this context (Agrawal \& Tiware, 2010; Sombsthay et al., 2019; Vats \& Tiwari, 2012). To see or receive daylight, integrated transparent and semi-transparent solar photovoltaic glasses could be replaced with ordinary windows (Munari et al., 2013). Office buildings are more suitable for BIPV applications because the panels generate electricity at approximately the same activity hours as the building (Lam et al., 2003).

Building-integrated photovoltaics contain many benefits, one of which is a cutback on construction and labor costs, compared to a building where photovoltaic cells were installed after the construction. The growing interest in BIPV is thanks to the fact that many countries today have turned to achieve near-zero buildings with no energy consumption. For BIPV systems to be versatile, several factors must be taken into consideration, including the temperature of the photovoltaic modules, the shade, the installation angle, and the rotation angle. Among these 
factors, the most important is the radiation and the temperature of the photovoltaic, because both, depending on the installation location, affect the electrical efficiency of the BIPV system and the energy performance of the building (Peng et al., 2011). Figure 2 shows an example of a BIPV facade of a high-rise building.

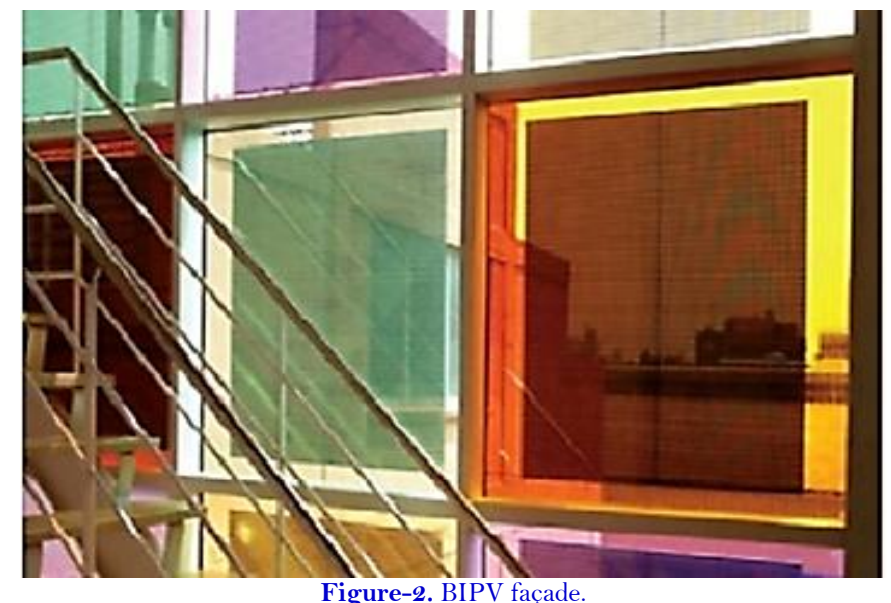

Source: Debbarma et al. (2017).

In this study, maximum sunlight efficiency to generate electricity and provide indoor illumination by using outdoor daylight in cold and dry climates, were simulated models for the envelope of a high-rise office building. The aesthetic dimension and use of new technologies with the minimum changes in the current structure of the existing building was considered, too.

\section{RESEARCH BACKGROUND}

In recent years, demand for new sources of sustainable energy has become one of the most challenging topics in global research (Chu \& Majumdar, 2012; Eslami, Gholami, Bakhtiari, Zandi, \& Noorollahi, 2019). That is due to the growing energy consumption worldwide. Industrialization and rapid growth of the global population have accelerated the search for applied renewable energy sources, with finding alternatives for fossil fuels as its ultimate goal (Kılkıs et al., 2019; Whiting, Carmona, Carrasco, \& Sousa, 2017). However, the multiplying demand from all over the world has led to a global pressure regarding energy consumption, suggesting that fossil fuels and sources must be replaced by low-cost, renewable ones by the means of fresh technologies in this domain (Kotilainen, Saari, Mäkinen, \& Ringle, 2019; Ostergaard, Duic, Noorollahi, Mikulcic, \& Kalogirou, 2020). Owing to a lack of land resources, urban areas are witnessing the growth of high-rise buildings. These crowded buildings are the leading consumers of energy (Aseem et al., 2017) so the need for local clean energy production is high (Poder, 2018).

For years, active solar technologies were merely being used as mechanical systems for electricity generation installed on buildings. Although some proposed solutions to create comfort in interior areas, hardly any attention was paid to their design and their combination with the architecture of buildings (Cappelletti, Nelli, \& Reatti, 2018). Since an adaptive facade is not a new issue for building skin sustainability, they have gone through various stages since the beginning of the 2oth century (Tabadkani, Valinejad Shoubi, Soflaei, \& Banihashemi, 2019).

Radwan and Osama (2016) concluded that management of building envelope design and materials leads to a significant decrease in energy consumption Radwan and Osama (2016). Heinstein, Ballif, and Perret-Aebi (2013) examined BIPV and solar panels as a typical cladding system for an integrated curtain wall and monolithic façade and articulated its advantages as an intelligent method (Heinstein et al., 2013). Semi-transparent and transparent PV in double or triple glazed elements have been used for building integration in the form of windows' photovoltaic glasses, which in addition to electricity generation, could let daylight into the building (Munari et al., 2013).

Springer et al. simulated the power generation in a building integrated with photovoltaics systems. Their study showed that the result of that integration as a component of thermal insulation in building coating as the electrical 
generation characteristics of the photovoltaic systems is well understood (Sprenger, Wilson, \& Kuhn, 2016). Yang and Burnett (2000) simulated and showed that by replacing a traditional wall with a BIPV wall, the cooling load could be reduced from 33 to $50 \%$ (Yang \& Burnett, 2000). Norton et al. mentioned that the net cost of installing such a system is much lower than a conventional photovoltaic system (Norton et al., 2011).

$\mathrm{Lu}$ and Law investigated the overall energy performance of a PV window, and the result showed that the proposed window was able to reduce the heat gain by $65 \%$ (Lu \& Law, 2013). Ng, Mithraratne, and Kua (2013) studied the energy-saving potential of BIPV was achieved with different BIPV and gained an energy-saving potential of $16.7-41.3 \%$ technologies ( $\mathrm{Ng}$ et al., 2013). Miyazaki et al. investigated that amorphous silicon (a-Si) double-glazed PV windows in their optimal configuration (40\% solar cell transfer and $50 \%$ window-to-wall ratio) could reduce total building electricity consumption by $55 \%$ compared to single-glazed windows (Miyazaki et al., 2005). Didoné and Wagner (2013) Performed extensive simulation to estimate the available annual daylight and the energetic performance of various window systems. Generally, the PV window offers the best energy performance for all facades, except for those with less solar radiation (Didoné \& Wagner, 2013). Li et al, studied daylight, solar radiation, and energy consumption fora-Si transparent photovoltaic, and showed a decrease in electric lighting and cooling energy requirements (12\% per year) and an increase in environmental benefits such as $\mathrm{CO}_{2}$ reduction as results., $\mathrm{SO}_{2}, \mathrm{NO}_{\mathrm{x}}$ ) (Li, Lam, Chan, \& Mak, 2009). Also, the results of Karamenis and Skandalos's study showed that translucent photovoltaics effectively reduce energy consumption in buildings (Skandalos \& Karamanis, 2015). Debbarma. et al. (2017) investigated that the use of transparent amorphous silicon (a-Si) thin film and its integration with the building in the windows that cover the front part of the building by changing the location of the building in terms of azimuth and reducing shadows revealed an up to $47 \%$ efficiency and improved energy production (Debbarma et al., 2017). Mirshojaeian, Saradj, Maddahi, and Ghobadian (2020) simulated building façades and compared the result of the window-to-wall ratio, building materials, and façade thickness between traditional-indigenous and modern building façades (Mirshojaeian et al., 2020).

According to a study conducted by Mirshojaeian et al. (2020) in Iran, the construction sector has a large share in energy consumption, meaning that the use of cheap energy and lack of proper thermal insulation for buildings, which leads to energy loss. It is of utmost importance to pay attention to this critical issue and find solutions for envelope design to reduce energy loss. The basic parameters in the performance of the outer shell of buildings are heat flow, air and humidity movement, air infiltration, solar energy, and natural illumination (Mirshojaeian et al., 2020).

The main research questions posed in this paper are as follows:

- How to provide maximum efficiency of sunlight in providing energy and interior lighting by an optimized model of an office building envelope?

- What feature in modern solar technologies, increases the focus on their use in high-rise buildings envelope to benefit from sunlight?

Based on the hypothesis set in this paper, it seems that by presenting an optimal model for the exterior shell of a high-rise office building, with the efficiency of renewable sources and reduction of environmental pollutants, it is possible to generate electricity while reducing artificial light consumption by using daylight.

On the other hand, assuming the efficiency of new solar technologies for producing electrical energy and maximum use of the facade area of today's high-rise buildings, without the view and landscape being limited, more efficiency of daylight and decrease in energy consumption can be seen.

Since Mashhad is a city situated in Iran, at latitude of $561836 \mathrm{~N}$ and $3459 \mathrm{E}$, cold and dry climate, and with average daylight hours during a year respectively 4.8 hours and 11.6 hours, this study aimed to optimize the facade of the YAS administrative-commercial tower in Mashhad, its daylight efficiency, and hence, electricity generation. Figures 3, and 4 show the south façade and azimuth of YAS Tower as the research case building. 


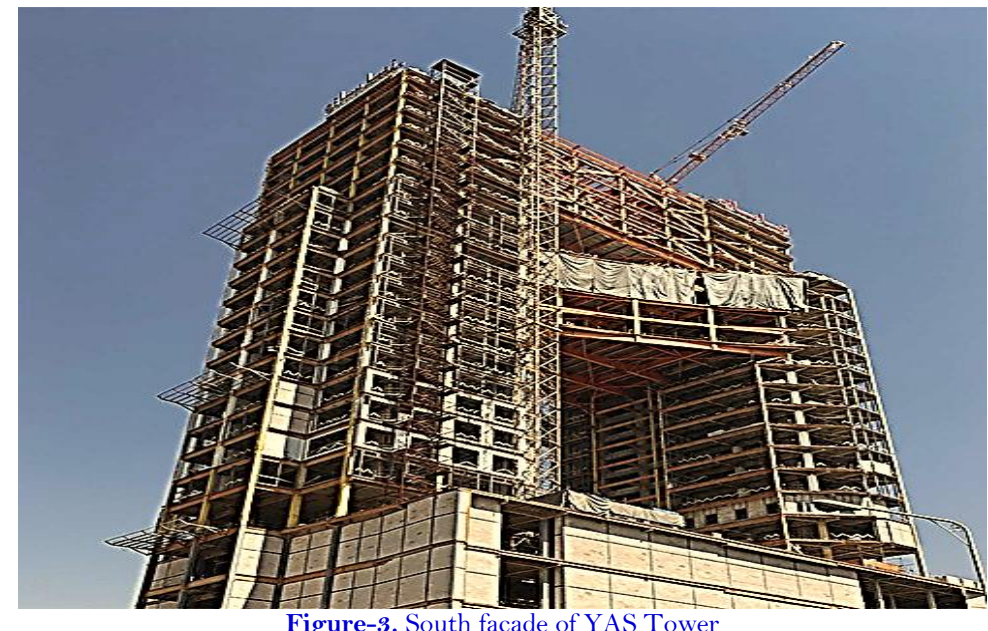

Source: http://www.ghaffari-trade.com

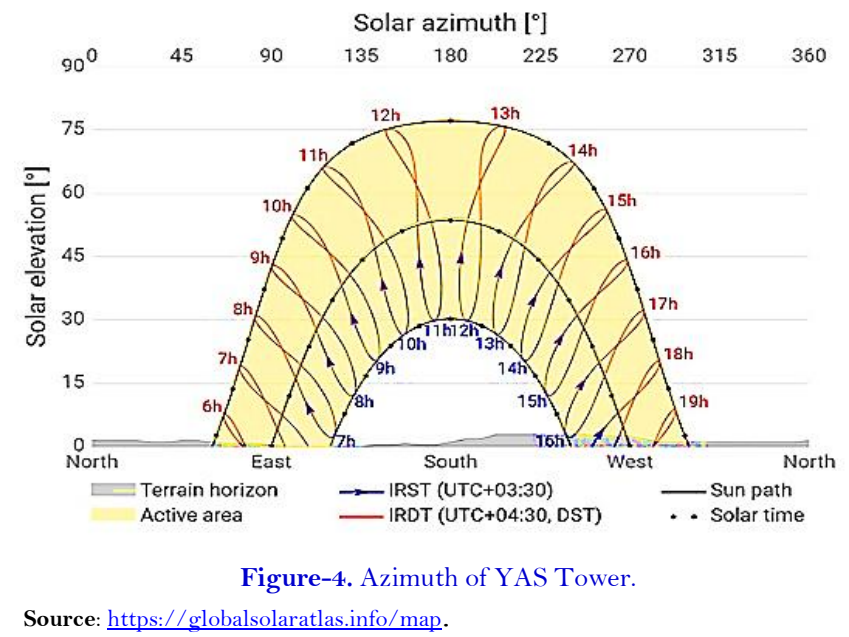

\section{RESEARCH METHODOLOGY}

This research has been conducted based on high-rise office building envelopes in the cold and dry climate of Mashhad, Iran. The research method was an analytical comparative approach by the printed sources found in the library, reliable internet scientific sources, and reviewing similar research. The geographical location of the case study suggests that the southern view is more suitable for benefitting from solar technology. In addition, two models were applied for the south facade of the business-office tower simulation by Design Builder software version 6.1.0.006, with the Energy plus 8.9 simulator engine. The models were proposed based on the applying transparent photovoltaic glasses and monocrystalline photovoltaic. Also, minimum changes and degradation in the existing building were considered. Models were proposed based on the use of transparent photovoltaic glasses and monocrystalline photovoltaic. Also, minimum changes and degradation in the appearance of the existing building were taken into consideration. This simulation has been performed assuming that the solar system is passive and on-grid, as well as all integrated photovoltaics, have equal efficiency (15\% efficiency). Energy consumption and electricity generation in the building were measured and calculated over a one-year period.

Then, based on the type and area of photovoltaics integrated with different parts of the building, efficiencies have undergone calculation for each model. Following that, through creating a proportionality between the data obtained from the electricity amount produced by each model in DesignBuilder software (with $15 \%$ efficiency) and the actual efficiency calculated by the same models, based on the efficiency of the proposed photovoltaics, the electricity generation amount for each was obtained and the results were evaluated. 


\section{DISCUSSION}

\subsection{Model Hypotheses}

This research has been conducted in cold and dry climates to investigate the electricity generation and efficiency of daylight in the photovoltaic facade. The DesignBuilder software has been used to evaluate the performance of the photovoltaic system in electricity generation. The cooling and heating system of the fan coil building has two pipes. The engine room equipment included a condensing boiler and a compression chiller. The thermal and refrigeration terminals of the building are ceiling fans with a water flow control valve in each room. Therefore, the temperature of each room can be controlled specifically. In the simulation of the building, the number of people, equipment, lighting system, as well as their performance is set by the template thanks to the Design Builder software standards. The heat transference Coefficient for the outer layer is $0.714 \mathrm{~W} / \mathrm{m}$. K and for the ceiling is $0.674 \mathrm{~W} / \mathrm{m}$. K.

\subsection{Solar Materials \\ 4.2.1 Low-E Photovoltaic glass}

In this research, Low-E photovoltaic glass with $20 \%$ transparency, an efficiency of $3.4 \%$, and maximum energy generation of $34 \mathrm{~W} / \mathrm{m}$. K has been employed because of the importance of internal daylight and maintaining the view of windows and curtain walls. The configuration and technical specification of the photovoltaic glass with $20 \%$ transparency have been defined.

\subsubsection{Configuration and the Standard Thickness of the 20\% Low-E Photovoltaic Glass}

Thickness Configuration (mm): $6 \mathrm{~T}+3.2 \mathrm{~F}+0.76 \mathrm{a}-\mathrm{Si}+0.76 \mathrm{P}+6 \mathrm{~T} / 12$ Argon/6T LOW-E

Total Thickness: $16.72 \mathrm{~mm}$

SHGC (\%): $12 \%$

$\mathrm{U}$ value $\mathrm{m}^{2}\left(\mathrm{~W} / \mathrm{m}^{2} \mathrm{~K}\right): 1.2$

$\mathrm{U}$ value $\mathrm{ft}^{2}\left(\mathrm{Btu} / \mathrm{ft}^{2} \mathrm{~F}\right): 0.21$

External Light Reflection (\%): $7.3 \%$

Transparency (\%): 20.0\%

Peak Power $\left(\mathrm{Wp} / \mathrm{m}^{2}\right): 34$

\subsubsection{Monocrystalline Photovoltaic}

In some spots of the building where internal daylight is not of much importance, the main alternatives like curtain wall frame, sealing, rooftop side of the pool wall and window O.K.B are the means suggested for the simulation models for the efficiency of the solar light. Monocrystalline panels with maximum energy generation of $500 \mathrm{Wp} / \mathrm{m} 2$ and maximum efficiency of $20.7 \%$ were used. Below, monocrystalline silicon photovoltaics, technical specifications have been shown

\subsubsection{Technical Specifications of Monocrystalline Photovoltaic Panels}

Peak Power Watts-P $\mathrm{P}_{\mathrm{MAx}}(\mathrm{Wp}): 500$

Power Tolerance-P $\mathrm{MAX}(\mathrm{W}): 0 \sim+5$

Maximum Power Voltage- $\mathrm{V}_{\text {MPP }}(\mathrm{V}): 43.4$

Maximum Power Current-I MPP (A): 11.53

Open Circuit Voltage- $V_{O C}(\mathrm{~V}): 51.5$

Short Circuit Current-ISC (A): 12.13

Module Efficiency $\mathrm{n}_{\mathrm{m}}$ (\%): 20.7 


\subsection{Suggested Models for Integrated BIPV in Cold and Dry Climate}

Tables 1, 2 and Figure 5 have rounded up the information of similar sections in both models that were covered with LOW-E solar photovoltaic glass with $20 \%$ transparency and monocrystalline photovoltaics.

Table-1. Information about southern facade and the area covered with LOW-E photovoltaic glass with $20 \%$ transparency in both models.

\begin{tabular}{l|c}
\hline Place of the LOW-E photovoltaic glass with $\mathbf{2 0} \%$ transparency & $\mathbf{A r e a ~}\left(\mathbf{m}^{2}\right)$ \\
\hline Small windows at right and left arm of the southern facade & 824.166 \\
\hline Suspended windows in the middle of the southern facade & 118.656 \\
\hline Both senary glassy parts in both low sides of the pool & 52.08 \\
\hline Both parts are individually glassed, at the top and both sides of the pool & 17.228 \\
\hline Vertical and horizontal part of the curtain wall & 672.055 \\
\hline South view of the pool wall & 244.7 \\
\hline
\end{tabular}

Table 2. Numbers of monocrystalline photovoltaic Panels in common with two models.

\begin{tabular}{l|c}
\hline Specified part to monocrystalline photovoltaic panel & Numbers of used panels \\
\hline Pool ceiling & 160 \\
\hline South view of the pool wall & 57 \\
\hline Horizontal curtain wall frame & 81 \\
\hline Vertical curtain wall frame & 108 \\
\hline
\end{tabular}

\subsubsection{Equations for Calculating the Efficiency of Models}

Total efficiency percentage equation of models:

$$
E \%=\frac{P_{t}(W)}{A_{t}\left(\mathrm{~m}^{2}\right) \times 10}
$$

Area monocrystalline photovoltaic panels' equation for models:

$$
\boldsymbol{N}_{P} \times \boldsymbol{A}_{p}\left(\mathrm{~m}^{2}\right)=\boldsymbol{A}_{\text {tmp }}\left(\mathrm{m}^{2}\right)
$$

Total power generated by the monocrystalline photovoltaic panels' equation for models:

$$
\boldsymbol{N}_{p} \times \boldsymbol{P}_{m}\left(\boldsymbol{W p} / \mathrm{m}^{2}\right)=\boldsymbol{P}_{m p}\left(\boldsymbol{W p} / \boldsymbol{m}^{2}\right)
$$

Equation Power generated by the LOW-E photovoltaic glass with $20 \%$ transparency in each model:

$$
\boldsymbol{A}_{t p g}\left(\boldsymbol{m}^{2}\right) \times \boldsymbol{P}_{m}\left(\boldsymbol{W p} / \mathrm{m}^{2}\right)=\boldsymbol{P}_{p g}\left(\boldsymbol{W p} / \boldsymbol{m}^{2}\right)
$$

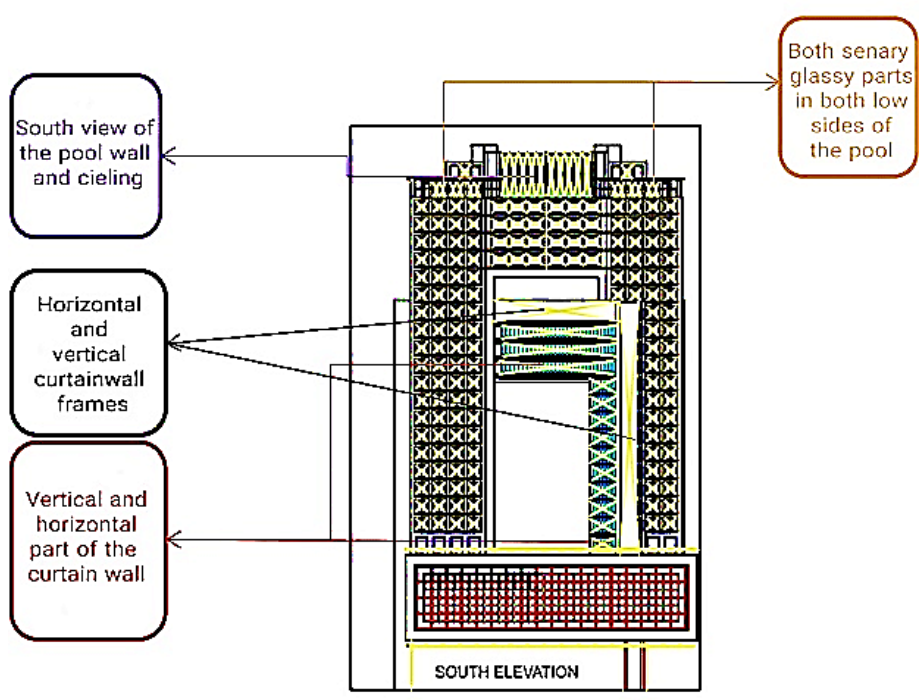

Figure-5. Model (\#1). 
4.3.2. Model Number One (\#1)

LOW-E photovoltaic glasses with 20\% transparency has been opted for windows in the southern facade of the "YAS" tower to use the most of solar energy and lower energy consumption and artificial light for internal illumination. The allocated sections to solar factors are identified with a cross mark $(\times)$ in Figure 5 , and the details are in Tables 3 and 4 .

Table 3. Areas of the dedicated parts to the model (\#1) solar factors.

\begin{tabular}{l|c}
\hline Dedicated parts to the monocrystalline photovoltaic panel & Numbers of the used panels \\
\hline Pool ceiling & 160 \\
\hline South view of the pool wall & 57 \\
\hline Horizontal curtain wall frame & 81 \\
\hline Vertical curtain wall frame & 108 \\
\hline Total panels & 406 \\
\hline
\end{tabular}

Table-4. Area of the dedicated sections to the solar factors in model (\#1).

\begin{tabular}{l|c}
\hline Dedicated sections to each solar factor & Area $\left(\mathbf{m}^{2}\right)$ \\
\hline Total sections dedicated to LOW-E photovoltaic glass $20 \%$ & 1684.185 \\
\hline Total sections dedicated to monocrystalline photovoltaic panels & 978.46 \\
\hline
\end{tabular}

The simulation results in DesignBuilder show that this building is using 162118 cubic meters of gas and $2785353 \mathrm{kWh}$ of electricity power with the model number one envelope, for one year. By using the numbers of photovoltaic panels mentioned in the table with 15\% efficiency, we can generate $769084 \mathrm{kWh}$ of electricity annually. In this case, $27.6 \%$ of the building's power consumption can be supplied with the photovoltaic system Table 5 .

Table-5. Summary of results KWh with $15 \%$ efficiency of model (\#1).

\begin{tabular}{|c|c|c|c|c|c|}
\hline Months & $\begin{array}{l}\text { Generated } \\
\text { electricity }\end{array}$ & $\begin{array}{l}\text { Received } \\
\text { radiation }\end{array}$ & $\begin{array}{c}\text { Heating system } \\
\text { energy }\end{array}$ & $\begin{array}{c}\text { Cooling system } \\
\text { energy }\end{array}$ & $\begin{array}{c}\text { Total energy of the heating } \\
\text { and cooling systems }\end{array}$ \\
\hline Jan & 62062 & 108245 & 530811 & $\mathrm{O}$ & 530811 \\
\hline Feb & 58578 & 110793 & 302232 & $\mathrm{O}$ & 302232 \\
\hline Mar & 61155 & 131206 & 143743 & $\mathrm{O}$ & 143743 \\
\hline Apr & 61119 & 148813 & $\mathrm{O}$ & 73604 & 73604 \\
\hline May & 60174 & 175030 & $\mathrm{O}$ & 216190 & 216190 \\
\hline Jun & 58813 & 184208 & $\mathrm{O}$ & 325333 & 325333 \\
\hline Jul & 63839 & 193059 & $\mathrm{O}$ & 401366 & 401366 \\
\hline Aug & 72644 & 189833 & $\mathrm{O}$ & 344154 & 344154 \\
\hline Sep & 79445 & 174979 & $\mathrm{O}$ & 225907 & 225907 \\
\hline Oct & 73255 & 144186 & $\mathrm{O}$ & 91961 & 91961 \\
\hline Nov & 59055 & 106955 & 244639 & $\mathrm{O}$ & 244639 \\
\hline Dec & 58944 & 100419 & 464601 & $\mathrm{O}$ & 464601 \\
\hline Total year & 769084 & 1767726 & 1686025 & 1678515 & 3364540 \\
\hline
\end{tabular}

Power generated by the allocated section to the LOW-E photovoltaic panel with $20 \%$ transparency with $3.4 \%$ efficiency and $34 \mathrm{Wp} / \mathrm{m}^{2}$ maximum power generation is:

$1684.185 \times 34=57262.29 \mathrm{Wp} / \mathrm{m}^{2}$

The area of the photovoltaic panel in model number One is:

$406 \times 2.41=978.46 \mathrm{~m}^{2}$

Power generated by the allocated section to the LOW-E photovoltaic panel with $20 \%$ transparency, with $20.7 \%$ efficiency, and $500 \mathrm{Wp} / \mathrm{m}^{2}$ maximum power generation is:

$406 \times 500=203000 \mathrm{Wp} / \mathrm{m}^{2}$

Calculation of the total efficiency for model number One is: 
$2602.29(\mathrm{~W})$

Model one efficiency $\%=$

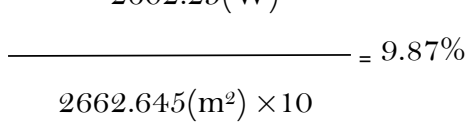

The amount of the generated electricity by model (\#1) is annually $501442.768 \mathrm{KWh}$ with making an electrical analogy with $15 \%$ efficiency (due to the panel type) and the suggested photovoltaic glass with $9.78 \%$ real efficiency within the simulation.

\subsubsection{Model Number Two (\#2)}

Model $(\# 2)$ is the same as model (\#1). The left and right wings of the building are the only difference. For O.K.B, monocrystalline photovoltaic is used in two wings, also their windows glasses are not photovoltaic. The dedicated sections to solar factors are identified with a cross mark $(\times)$ in Figure 6 and detail in Tables 6 and 7 .

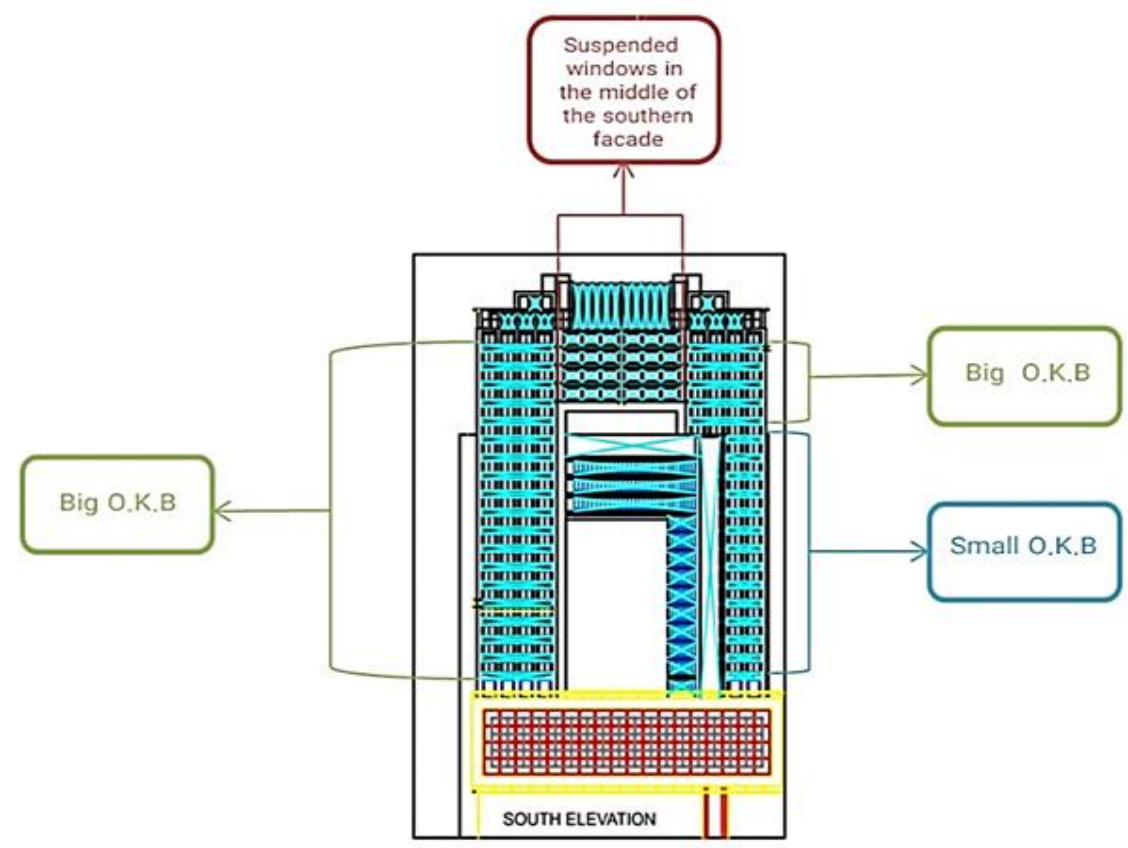

Figure-6. Model (\#2)

Table-6. Areas of the dedicated parts to the model \#2 solar factors.

\begin{tabular}{l|l}
\hline Dedicated sections to each solar part & Area $\left(\mathbf{m}^{2}\right)$ \\
\hline Total section dedicated to LOW-E photovoltaic glass with $20 \%$ transparency & 860.019 \\
\hline Total section dedicated to monocrystalline photovoltaic panel & 1484.54 \\
\hline
\end{tabular}

Table-7. Dedicated section to monocrystalline photovoltaic panel and their number in model (\#2).

\begin{tabular}{l|c}
\hline Dedicated parts to the monocrystalline photovoltaic panel & Numbers of the used panels \\
\hline Pool ceiling & 160 \\
\hline Pool side wall & 57 \\
\hline Horizontal curtain wall frame & 81 \\
\hline Vertical curtain wall frame & 108 \\
\hline Big and small O.K.B in right and left arms of the southern facade & 210 \\
\hline Total panels & 616 \\
\hline
\end{tabular}

The results given by simulation for model (\#2) envelope are 162118 cubic meters of gas use and $2785370 \mathrm{kWh}$ electricity used annually. By using these many panels with $15 \%$ efficiency, we can generate $521814 \mathrm{kWh}$ electricity annually. In this case, $18.7 \%$ of this electricity can be generated with the photovoltaic system Table 8 . 
Table-8. Summary of the KWh results with $15 \%$ efficiency for model (\#2).

\begin{tabular}{c|c|c|c|c|c}
\hline Months & $\begin{array}{c}\text { Generated } \\
\text { electricity }\end{array}$ & $\begin{array}{c}\text { Received } \\
\text { radiation }\end{array}$ & $\begin{array}{c}\text { Heating } \\
\text { system energy }\end{array}$ & $\begin{array}{c}\text { Cooling } \\
\text { system energy }\end{array}$ & $\begin{array}{c}\text { Total energy of the heating } \\
\text { and cooling systems }\end{array}$ \\
\hline Jan & 37935 & 108245 & 530811 & 0 & 530811 \\
\hline Feb & 36837 & 110793 & 302231 & 0 & 302231 \\
\hline Mar & 40728 & 131206 & 143742 & 0 & 143742 \\
\hline Apr & 42826 & 148814 & 0 & 73605 & 73605 \\
\hline May & 45390 & 175030 & 0 & 216193 & 216193 \\
\hline Jun & 45965 & 184209 & 0 & 325336 & 325336 \\
\hline Jul & 48843 & 193059 & 0 & 401369 & 341369 \\
\hline Agu & 51970 & 189833 & 0 & 344157 & 225910 \\
\hline Sep & 52589 & 174980 & 0 & 225910 & 91962 \\
\hline Oct & 46482 & 144186 & 0 & 91962 & 244639 \\
\hline Nov & 36519 & 106955 & 244639 & 0 & 464601 \\
\hline Dec & 35729 & 100419 & 464601 & 0 & 3364557 \\
\hline Total year & 521814 & 1767729 & 1686025 & 1678532 & \\
\hline
\end{tabular}

Calculation of the total efficiency for model number Two:

$$
337240.646(\mathrm{~W})
$$

Model two efficiency $\%=-9.87 \%$

$$
2344.559\left(\mathrm{~m}^{2}\right) \times 10
$$

The amount of the generated electricity by model $(\# 2)$ is annually $499202.06 \mathrm{KWh}$ with making an electrical analogy with $15 \%$ efficiency (due to the panel type) and the suggested photovoltaic glass with $14.38 \%$ real efficiency within the simulation.

\section{RESULTS}

As per Table 9 of Figure 7, the comparison of the results obtained from the two proposed models with the same efficiency for both models, which is $15 \%$, the highest generation of electricity is feasible with model (\#1), with generated electricity amount of $769084 \mathrm{kWh}$. After that, model (\#2) comes in line, with generated electricity, $521814 \mathrm{kWh}$ per year.

\begin{tabular}{|c|c|c|}
\hline & Generated electricity & Percentage of electricity supply of total KWh \\
\hline Model & KWh & \\
\hline One & 769084 & 27.6 \\
\hline Two & 52181 & 18.7 \\
\hline
\end{tabular}

Table-9. Summary results of the amount of electricity Generated with $15 \%$ efficiency.

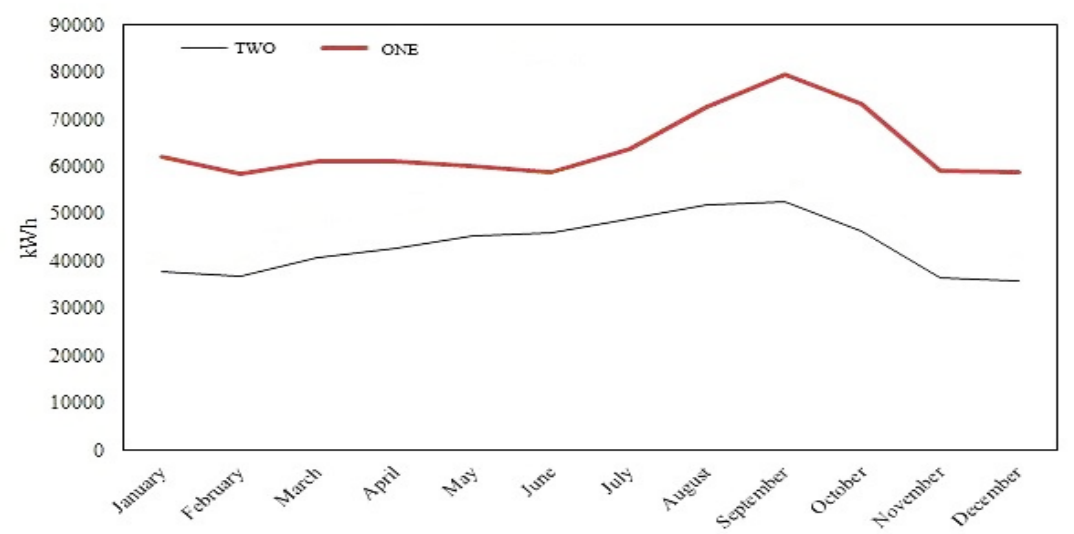

Figure-7. Comparison of electricity generation results of Proposed models with $15 \%$ efficiency. 
According to Table 10 and Figure 8, the comparison of the results obtained from the two proposed models with different calculated efficiencies showed that the highest generation of electricity happens with model (\#1), with generated electricity amount of $768 / 501442 \mathrm{kWh}$. After that, model (\#2) is in line, with generated electricity amounting to $4999,062 \mathrm{kWh}$ annually.

Table-10. Summary results of the amount of electricity generated with the calculated efficiency.

\begin{tabular}{c|c|c|c}
\hline Model & $\begin{array}{c}\text { Generated electricity } \\
\text { KWh }\end{array}$ & $\begin{array}{c}\text { Percentage of electricity } \\
\text { supply of total KWh }\end{array}$ & Efficiency \\
\hline One & 501442.768 & 17.99 & $9.78 \%$ \\
\hline Two & 499202.06 & 17.88 & $14.38 \%$ \\
\hline
\end{tabular}

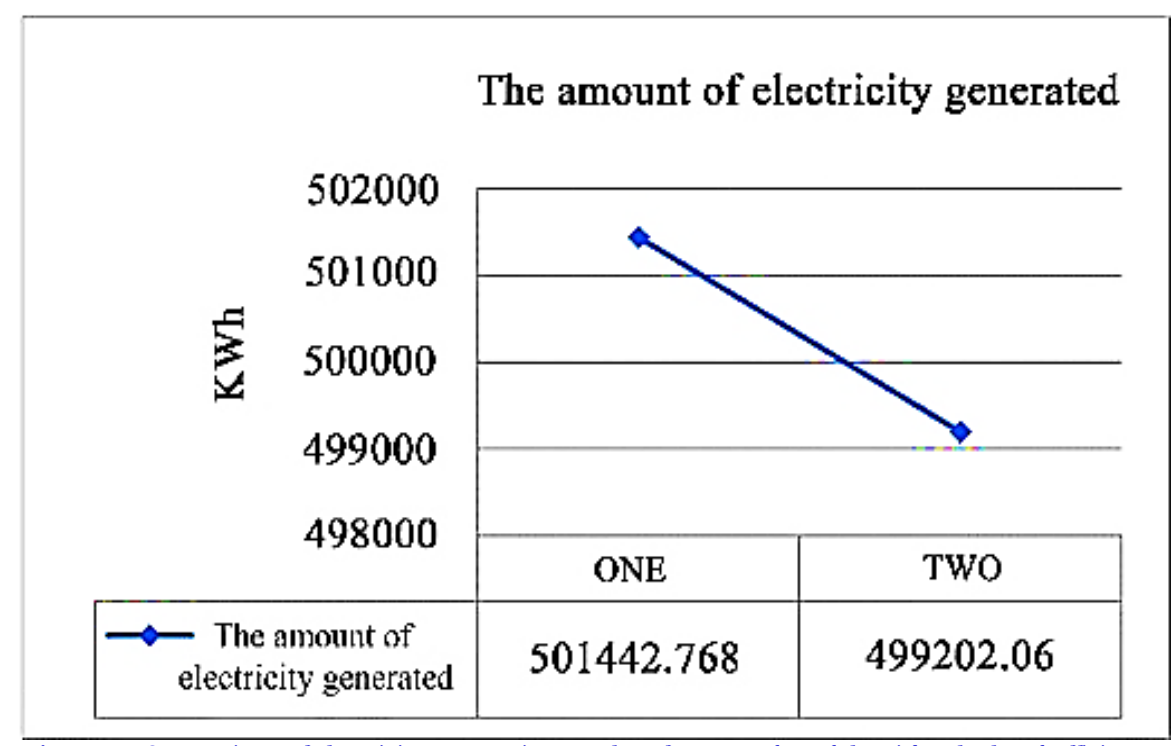

Figure-8. Comparison of electricity generation results of Proposed models with calculated efficiency.

\section{CONCLUSIONS}

The transition to zero-energy buildings to reduce macro and micro-climate changes, can be realized only when advanced steps are taken in building materials, using renewable energy instead of fossil fuel energy sources. In this context, cooling and lighting loads have gone down significantly, while generating electricity, and energy-saving potentials have increased.

Consequently, PV systems can be a good choice. The results of examining the models with $15 \%$ efficiency and the calculated efficiency based on the type of photovoltaic glass and photovoltaic panels, showed that, in both cases, model (\#1) generates the largest amount of electricity. However, the observed difference in electricity generation for model (\#1) and model (\#2) with the same efficiency (15\%) triumphs over those with calculated efficiency.

Therefore, in addition to climatic factors, the angle of radiation, the intensity of sunlight, shading of adjacent buildings, and keeping the panels clean, the following three factors in the amount of electricity generated by the building that the envelope is effective for utilizing daylight and generating electricity with coated photovoltaic panels are as such:

1) The total area allocated to panels and solar agents to generate electricity.

2) Type and efficiency of panels.

3) The area in which each type of panel, with its efficiency, occupies the total area of the envelope.

Based on our findings for the question put by this research, we can declare that a vast variety of options come at hand once the optimal model presented and new generation photovoltaics are used, compared to their installation and application in the envelope of the building. 
Invariably, the results suggest that by using new technologies and combining solar photovoltaics with transparency and double-glazed capabilities -which cause low heat transfer and prevent the penetration of harmful solar radiation (Infrared and Ultraviolet rays) -with monocrystalline photovoltaics and also, appropriate design for their placement in the envelope of high-rise office buildings, even built, and existing buildings, caused the envelope to be optimized.

And still, it performed maximum efficiency of daylight with the supply of electrical energy. Finally, it reduced energy consumption by applying minimal changes to the existing structure of buildings. Likewise, this may allow us to go further in the domain of promoting new solar technologies application in similar geographical locations and cold and dry climates by reducing installation and implementation costs.

$\begin{array}{llll}\text { Abbreviations } & & \\ \text { E\% } & \text { Efficiency percentage (W) } & \text { PV } & \text { Photovoltaic } \\ \text { NP } & \text { Numbers of panels } & \text { BIPV } & \text { Building-Integrated Photovoltaics } \\ \text { Ap } & \text { Area of each panel }(\mathrm{m} 2) & \text { O.K.B } & \text { Ocopenci Kingstone Benchmark } \\ \text { Atpg } & \text { Area of the total photovoltaic glasses } & \text { LOW-E } & \text { Low Emissivity } \\ & \text { with } 20 \% \text { transparency }(\mathrm{m} 2) & \mathrm{T} & \text { Tempered Glass } \\ \text { Ppg } & \text { Power generated by the } & \mathrm{F} & \text { Float Glass } \\ & \text { photovoltaic glasses }(\mathrm{Wp} / \mathrm{m} 2) & \mathrm{P} & \text { PVB (Polyvinyl Butyral) Foils } \\ \text { Pm } & \text { Maximum generated power }(\mathrm{Wp} / \mathrm{m} 2) & \text { a-Si } & \text { Amorphous Silicon Thin Film Solar Cells } \\ \mathrm{Pt} & \text { Total power of the photovoltaic glass } & \text { SHGC } & \text { Solar Heat Gain Coefficient } \\ & \text { and panels used for each model } & & \\ \text { Pmp } & \text { Power generated by monocrystalline } & & \\ & \text { panel (Wp/m2) } & & \end{array}$

Funding: This study received no specific financial support.

Competing Interests: The authors declare that they have no competing interests.

Acknowledgement: All authors contributed equally to the conception and design of the study.

\section{REFERENCES}

Agrawal, B., \& Tiware, G. N. (2010). Optimizing the energy and exergy of building integrated photovoltaic thermal (BIPVT) systems under cold climatic conditions. Applied Energy, 87(2), 417-426. Available at: https://doi.org/10.1016/j.apenergy.2009.06.011.

Aseem, K., Sharma, A., \& Kothari, D. P. (2017). Solar PV Facade for High-rise Buildings in Mumbai. International Journal of Civil Engineering Research, 8(1), 15-32.

Ballif, C., Perret-Aebi, L.-E., Lufkin, S., \& Rey, E. (2018). Integrated thinking for photovoltaics in buildings. Nature Energy, 3(6), 438-442. Available at: https://doi.org/10.1038/s41560-018-0176-2.

Borbon-Almada, A. C., Rodriguez-Muñoz, N. A., \& Najera-Trejo, M. (2019). Energy and economic impact on the application of low-cost lightweight materials in economic housing located in dry climates. Sustainability, 11(6), 1586. Available at: https://doi.org/10.3390/su1 1061586.

Cappelletti, A., Nelli, L. C., \& Reatti, A. (2018). Integration and architectural issues of a photovoltaic/thermal linear solar concentrator. Solar Energy, 169, 362-373. Available at: https://doi.org/10.1016/j.solener.2018.05.013.

Chae, Y. T., Jeehwan, K., Park, H., \& Byungha, S. (2014). Bulding energy performance evaluation of intigrated photovoltaic (BIPV) window with semi-transparent solar cells. Applied Energy, 129, 217-227. Available at: https://doi.org/10.1016/j.apenergy.2014.04.106.

Chen, K.-S., Salinas, J.-F., Yip, H.-L., Huo, L., Hou, J., \& Jen, A. K.-Y. (2012). Semi-transparent polymer solar cells with 6\% PCE, $25 \%$ average visible transmittance and a color rendering index close to 100 for power generating window applications. Energy ङ̊ Environmental Science, 5(11), 955 1-9557. Available at: https://doi.org/10.1039/c2ee22623e.

Chu, S., \& Majumdar, A. (2012). Opportunities and challenges for a sustainable energy future. Nature, 488(7411), $294-303$. 
Debbarma, M., Sudhakar, K., \& Baredar, P. (2017). Review article comparison of BIPV and BIPVT: A review. Resource-Efficient Technologies, 3(3), 263-271. Available at: https://doi.org/10.1016/j.reffit.2016.11.013.

Debbarma, M., Sudhakar, K., \& Baredar, P. (2017). Comparison of BIPV and BIPVT: A review. Resource-Efficient Technologies, 3(3), 263-271. Available at: https://doi.org/10.1016/j.reffit.2016.11.013.

Didoné, E. L., \& Wagner, A. (2013). Semi-transparent PV windows: A study for office buildings in Brazil. Energy and Buildings, 67, 136-142. Available at: https://doi.org/10.1016/j.enbuild.2013.08.002.

Eiffert, P. (2000). Building-integrated photovoltaic designs for commercial and institutional structures: A sourcebook for architects: DIANE Publishing.

Eslami, S., Gholami, A., Bakhtiari, A., Zandi, M., \& Noorollahi, Y. (2019). Experimental investigation of a multi-generation energy system for a nearly zero-energy park: A solution toward sustainable future. Energy Conversion and Management, $200,112107$.

EU. (2010). Directive 2010/31/eu of the european parliament and of the council of 19 May 2010 on the energy performance of buildings, Retrieved from: https://eur-lex.europa.eu/legal-content/en/TXT/?uri=CELEX\%3A32010L0031\#ntr9L_2010153EN.01001301-E0009.

Hachem, C., Athienitis, A., \& Fazio, P. (2014). Energy performance enhancement in multistory residential buildings. Applied Energy, 116, 9-19. Available at: https://doi.org/10.1016/j.apenergy.2013.11.018.

Heinstein, P., Ballif, C., \& Perret-Aebi, L. E. (2013). Building integrated photovoltaics (BIPV): Review, potentials, barriers and myths. Green, 3(2), 125-156. Available at: https://doi.org/10.1515/green-2013-0020.

Henemann, A. (2008). BIPV: Built-in solar energy. Renewable Energy Focus, 9(6), 14-19.

IRENA. (2019). Future of solar photovoltaic. Retrieved from: https://irena.org//media/Files/IRENA/Agency/Publication/2019/Nov/IRENA_Future_of_Solar_PV_2019.pdf.

Jiang, Z., Zhou, Y., Lu, F., Han, Z., \& Wang, T. (2008). Effects of different levels of supplementary alpha-amylase on digestive enzyme activities and pancreatic amylase mRNA expression of young broilers. Asian-Australasian Journal of Animal Sciences, 21(1), 97-102. Available at: https://doi.org/10.5713/ajas.2008.70110.

Khoo, Y. S., Nobre, A., Malhotra, R., Yang, D., Rüther, R., Reindl, T., \& Aberle, A. G. (2013). Optimal orientation and tilt angle for maximizing in-plane solar irradiation for PV applications in Singapore. IEEE Journal of Photovoltaics, 4(2), 647-653.

Kılkıs, S., Krajačic, G., Duic, N., Montorsi, L., Wang, Q., \& Rosen, M. (2019). Research frontiers in sustainable development of energy, water and environment systems in a time of climate crisis. Energy Conversion and Management, 199, 111938 111959. Available at: http://dx.doi.org/10.1016/j.enconman.2019.111938.

Kotilainen, K., Saari, U. A., Mäkinen, S. J., \& Ringle, C. M. (2019). Exploring the microfoundations of end-user interests toward co-creating renewable energy technology innovations. Journal of Ceaner Production, 229, 203-212. Available at: https://doi.org/10.1016/j.jclepro.2019.04.296.

Lam, J., Li, D., \& Cheung, S. (2003). An analysis of electricity end-use in air-conditioned office buildings in Hong Kong. Building and Environment, 38(3), 493-498.

Li, D. H., Lam, T. N., Chan, W. W., \& Mak, A. H. (2009). Energy and cost analysis of semi-transparent photovoltaic in office buildings. Applied Energy, 86(5), 722-729. Available at: https://doi.org/10.1016/j.apenergy.2008.08.009.

Lu, L., \& Law, K. M. (2013). Overall energy performance of semi-transparent single-glazed photovoltaic (PV) window for a typical office in Hong Kong. Renewable Energy, 49, 250-254. Available at: https://doi.org/10.1016/j.renene.2012.01.021.

Maturi, L., \& Adami, J. (2018). Building integrated photovoltaic (BIPV) in Trentino alto adige, Green energy and technology (pp. 1-89). Cham: Springer.

Mirshojaeian, H. I., Saradj, F. M., Maddahi, S. M., \& Ghobadian, V. (2020). Enhancing the façade efficiency of contemporary houses of Mashhad, using the lessons from traditional buildings. International Journal of Energy and Environmental Engineering, 11(4), 417-429. 
Miyazaki, T., Akisawa, A., \& Kashiwagi, T. (2005). Energy savings of office buildings by the use of semi-transparent solar cells for windows. Renewable Energy, 30(3), 281-304. Available at: https://doi.org/10.1016/j.renene.2004.05.010.

Munari, P. M. C., Roecker, C., Frontini, F., Scognamiglio, A., Farkas, K., Maturi, L., \& Zanetti, I. (2013). Solar energy systems in architecture-integration criteria and guidelines. International Energy. Report T.41.A.2: IEA SHC Task 41 Solar Energy and Architecture.

Nagy, Z., Svetozarevic, B., Jayathissa, P., Begle, M., Hofer, J., Lydon, G., . . S Schlueter, A. (2016). The adaptive solar facade: From concept to prototypes. Frontiers of Architectural Research, 5(2), 143-156.

Ng, P. K., Mithraratne, N., \& Kua, H. W. (2013). Energy analysis of semi-transparent BIPV in Singapore buildings. Energy and Buildings, 66, 274-281. Available at: https://doi.org/10.1016/j.enbuild.2013.07.029.

Norton, B., Eames, P. C., Mallick, T. K., Huang, M. J., McCormack, S. J., Mondol, J. D., \& Yohanis, Y. G. (2011). Enhancing the performance of building integrated photovoltaics. Solar Energy, 85(8), 1629-1664.

Nouhi, H. R. (2000). Reflections on art and architecture (pp. 40-62). Tehran, Iran: Gamnou.

Ostergaard, P. A., Duic, N., Noorollahi, Y., Mikulcic, H., \& Kalogirou, S. (2020). Sustainable development using renewable energy technology. Renewable Energy, 146, 2430-2437. Available at: https://doi.org/10.1016/j.renene.2019.08.094.

Peng, C., Huang, Y., \& Wu, Z. (2011). Building-integrated photovoltaics (BIPV) in architectural design in China. Energy and Buildings, 43(12), 3592-3598. Available at: https://doi.org/10.1016/j.enbuild.2011.09.032.

Pester, S., \& Crick, F. (2013). Performance of photovoltaic systems on non-domestic buildings (pp. 1-55). Garston Watford Herts: IHS BRE Press.

Poder, S. (2018). Potentials and challenges of facade mounted PV in Urban areas-with copenhagen International School as Case. DTU Master Thesis, 19(1), 105-108.

Radwan, G. A., \& Osama, N. (2016). Biomimicry, an approach, for energy effecient building skin design. Procedia Environmental Sciences, 34, 178-189. Available at: https://doi.org/10.1016/j.proenv.2016.04.017.

Siddiqui, F. Y., Shaikh, S. U., Upadhye, D. S., Huse, N. P., Dive, A. S., \& Sharma, R. (2017). Investigation on the effect of copper doping on CdS1-xSex thin films. Ferroelectrics, 518(1), 153-162.

Skandalos, N. N., \& Karamanis, N. D. (2015). PV glazing technologies, Contents lists available at Science direct. Renewable and Sustainable Energy Reviews, 49(C), 306-322. Available at: https://doi.org/10.1016/j.rser.2015.04.145.

Sombsthay, A., Beauvais, A., Moser, D., Tecnalia, E. B., Gaymard, G., Delmer, G., . . Krawietz, S. (2019). Solar skins: An opportunity for green cities. Brussels Belgium: Solar Power Europe and ETIP PV.

Sonnenenergie, D. G. (2008). Planning and installing photovoltaic systems: A guide for installers, architects and engineers (pp. 199-270). UK: Earthscan-2.

Sprenger, W., Wilson, H. R., \& Kuhn, T. E. (2016). Electricity yield simulation for the building-integrated photovoltaic system installed in the main building roof of the Fraunhofer Institute for Solar Energy Systems ISE. Solar Energy, 135, 633643. Available at: https://doi.org/10.1016/j.solener.2016.06.037.

Stamatakis, A., Mandalaki, M., \& Tsoutsos, T. (2016). Multi-criteria analysis for PV integrated in shading devices for Mediterranean region. Energy and Buildings, 117, 128-137. Available at: https://doi.org/10.1016/j.enbuild.2016.02.007.

Strong, S. (2016). Building integrated photovoltaics (BIPV). Whole Building Design Guide, Updated: 10-19-2016. Retrieved from: https://www.wbdg.org.

Tabadkani, A., Valinejad Shoubi, M., Soflaei, F., \& Banihashemi, S. (2019). Integrated parametric design of adaptive facades for user's visual comfort. Automation in Construction, 106, 102857. Available at: https://doi.org/10.1016/j.autcon.2019.102857.

Vats, K., \& Tiwari, G. (2012). Performance evaluation of a building integrated semitransparent photovoltaic thermal system for roof and façade. Energy and Buildings, 45, 21 1-2 18. Available at: https://doi.org/10.1016/j.enbuild.2011.11.008.

Wang, J., Liao, M., Lee, Y., Liu, C., Kuo, K., \& Chou, C. (2018). On enhancing energy harvesting performance of the photovoltaic modules using an automatic cooling system and assessing its economic benefits of mitigating greenhouse effects on the environment. Journal of Power Sources, 376, 55-65. Available at: https://doi.org/10.1016/j.jpowsour.2017.1 1.051. 
Whiting, K., Carmona, L. G., Carrasco, A., \& Sousa, T. (2017). Exergy replacement cost of fossil fuels: Closing the carbon cycle. Energies, 1O(7), 1-6. Available at: https://doi.org/10.3390/en10070979.

World Energy Resources. (2013). Survey: World energy council. 20. Retrieved from: http://www.IEA.org.

Xu, L., Reed, M., \& Reindl, T. (2016). CityGML and solar potential analysis for buildings in Singapore. Paper presented at the In: Proceedings of the 6th Workshop CityGMLEnergy ADE, Ferrara, Italy.

Yang, H., \& Burnett, J. (2000). Simple approach to cooling load component calculation through PV walls. Energy Build, $31(3)$, 285-290. Available at: https://doi.org/10.1016/s0378-7788(99)00041-9.

Zawidzki, M. (2015). Dynamic shading of a building envelope based on rotating polarized film system controlled by onedimensional cellular automata in regular tessellations (triangular, square and hexagonal). Advanced Engineering Informatics, 29(1), 87-100. Available at: https://doi.org/10.1016/j.aei.2014.09.008.

Views and opinions expressed in this article are the views and opinions of the author(s), International Journal of Sustainable Energy and Environmental Research shall not be responsible or answerable for any loss, damage or liability etc. caused in relation to/arising out of the use of the content. 